\title{
Zöld információs társadalom a gazdaságban
}

A tanulmány azzal foglalkozik, hogy informatikai szempontból milyen mértékben környezettudatosak a hazai középvállalatok. A szerzők a különböző IKT eszközfajták (PC-k, szerverek, nyomtatók) egész „életciklusán” keresztül (beszerzés, üzemeltetés, selejtezés) részletesen megvizsgálták a környezeti szempontok érvényesülését. Az eredmények azt mutatják, hogy a környezettudatos magatartás megvalósulásához vezető út fontos állomása az informatikai stratégia elkészítése, mert ez legalább is felszínre hozza a problémákat, jobb esetben pedig megteremti az alapot az energiahatékonyság méréséhez is. A kutatás fontos tanulsága, hogy a vállalatok egyelőre elég passzívak, vagyis csak azokon a területeken vannak tekintettel a környezet védelmére, ahol ez viszonylag egyszerüen megoldható.

Kulcsszavak: Környezettudatosság, „zöld” információs társadalom, kis- és Zözépvállalatok

\section{Szerzői információ:}

\section{Lôrincz Vilmos}

Közgazdász, 2001 óta dolgozik a GKI gazdaságkutató vállalatcsoportnál. Jelenleg a GKIeNET Kft. munkatársa. Doktori tanulmányait a BME-n folytatja a kis- és középvállalati szektor fejlődési lehetőségeinek témakörében. Kutatási területei: az információs technológiai eszközök vállalati alkalmazása, vállalatirányítási és üzleti intelligenciarendszerek használata, informatikai környezettudatosság, valamint az információs társadalom fejlődése.

\section{Nagy Dávid}

Közgazdász, 2007 óta a GKIeNET Kft. kutatója. Kutatási témái az információs társadalom fejlódéséhez kapcsolódnak, fó érdeklődési területe az IT és telekommunikációs eszközök terjedése és használata.

Így hivatkozzon erre a cikkre:

Lőrincz Vilmos, Nagy Dávid. „Zöld információs társadalom a gazdaságban.” Információs Társadalom IX, 3. szám (2009): 94-102. https://dx.doi.org/10.22503/inftars.IX.2009.3.6

A folyóiratban közölt müvek

a Creative Commons Nevezd meg! - Ne add el! - Így add tovább! 4.0

Nemzetközi Licenc feltételeinek megfelelően használhatók. 
Nagy Dávid - Lốrincz Vilmos

\section{Zöld információs társadalom a gazdaságban}

Az informatikai eszközök gyorsuló ütemben terjedtek az ezredforduló óta eltelt években. A világon több mint egymilliárd személyi számítógép van használatban, és a múködố szerverek száma is meghaladja a 30 milliót. A növekedés nem áll le, 2014-ig várható a számítógépek számának újabb megkétszereződése.

Az informatikai eszközök is fontos szerepet játszanak abban, hogy az emberiség energiafogyasztása folyamatosan nô. A kérdés mindannyiunkat érint, csak más-más szinten, hiszen a rengeteg egyéni felhasználó fogyasztása összemérhetố a nagy szerverfarmokéval, de a kérdést vizsgálhatjuk a gyártók és a felhasználók viszonylatában is.

A gyártók egy része - felismerve saját felelősségét - már évek óta ezt a szempontot is figyelembe véve fejleszti az eszközöket, hogy azok hatásfoka minél jobb legyen. Kérdés azonban, hogy a vállalatok mennyire viselkednek tudatosan, rájöttek-e arra, hogy ha takarékosabb eszközöket vásárolnak, hosszú távon jelentôs összegeket takaríthatnak meg. A villamosenergia-felhasználáson túl komoly környezeti terhet jelent a nyomtatási tevékenység is. Ebben az esetben hiába készítenek a gyártók mind energia-, mind tintafelhasználás tekintetében egyre gazdaságosabb eszközöket, a papírfelhasználás mérséklése kizárólag vállalati kultúra kérdése.

A GKIeNET Kft. a Sun Microsystems megbízásából arra kereste a választ, hogy ebben a tekintetben mennyire ,zöldek” a vállalatok. Vizsgálatunk célpontjául a legalább ötven számítógéppel rendelkezô vállalatokat jelöltük ki, amelyeknél már meg lehet állapítani az informatikai infrastruktúra múködtetési költségeit és azok jelentôségét a vállalat gazdálkodásában. A felmérés 2009 tavaszán készült országosan reprezentatív mintán.

A kiadások forintosítása mellett hangsúlyt helyeztünk annak bemutatására is, hogy a vállalatok milyen mértékben figyelnek a környezetbarát múködésre az eszközök életciklusának különbözô fázisaiban. Kérdéseink a következókre irányultak: beszerzéskor figyelembe veszik-e a termékek minôsítését, milyen szerepet játszik az energiahatékonyság és a környezettudatosság, a használat során milyen lépéseket tesznek a takarékosság érdekében, a vállalati kultúra és a dolgozók mennyiben tekinthetók környezettudatosnak például a nyomtatási gyakorlat tekintetében, s végül a selejtezés során miként szabadulnak meg fölöslegessé vált eszközeiktól.

Az elemzés során elôször röviden bemutatjuk az IT-infrastruktúra kiterjedtségét, majd becslést készítünk az energiafelhasználásra vonatkozóan. Ezt követốen részletezzük az említett életciklus-vizsgálat eredményeit. 


\section{Az informatikai infrastruktúra mérete}

Általánosságban igaz, hogy minél nagyobb a vállalat, annál kisebb a számítógépet használó dolgozók aránya. A kisebb cégeknél ez az arány $50 \%$ fölött is lehet, míg a nagyvállalatok esetében inkább egyharmad körül alakul. Ezt természetesen az iparági jellegzetességek is befolyásolják: elsősorban a feldolgozóiparra jellemzó, hogy magasabb létszám mellett alacsonyabb a számítógépek száma.

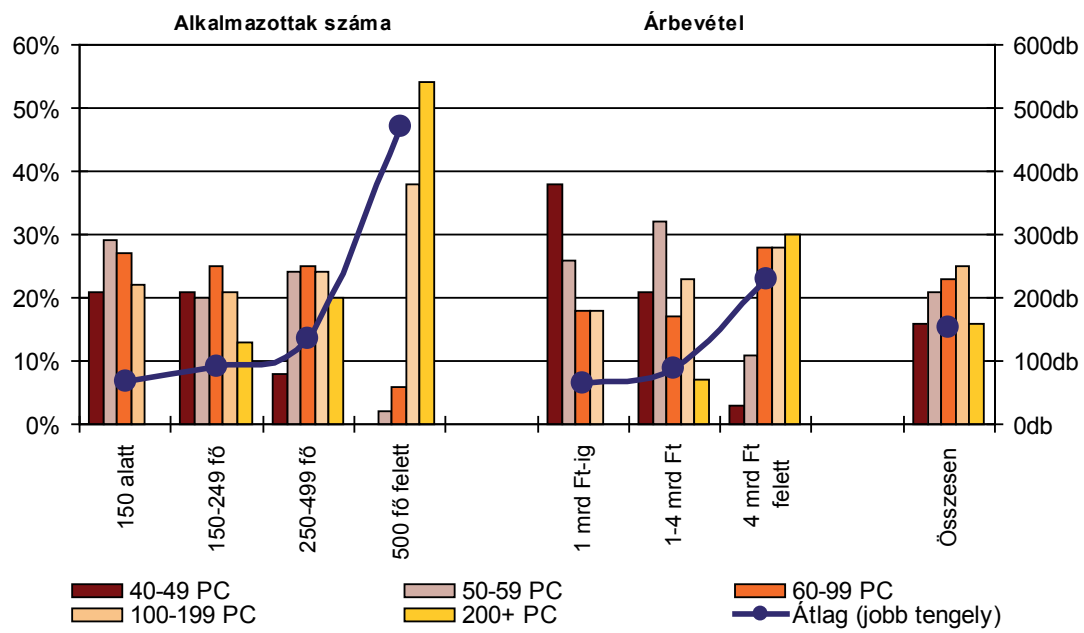

1. ábra

$A$ vállalati $p c-k$ sæáma

A legalább 40 számítógéppel rendelkezố cégek körében szinte minden vállalatnak (93\%) van saját szervere, amely az energiafogyasztás szempontjából kiemelkedố fontosságú eszköz. A szerverállomány mérete vegyes képet mutat, ugyanis a cégeknek majdnem a felének csak 1-4 db szervere van, több mint negyedrészük (27\%) azonban legalább 10 szervert üzemeltet.

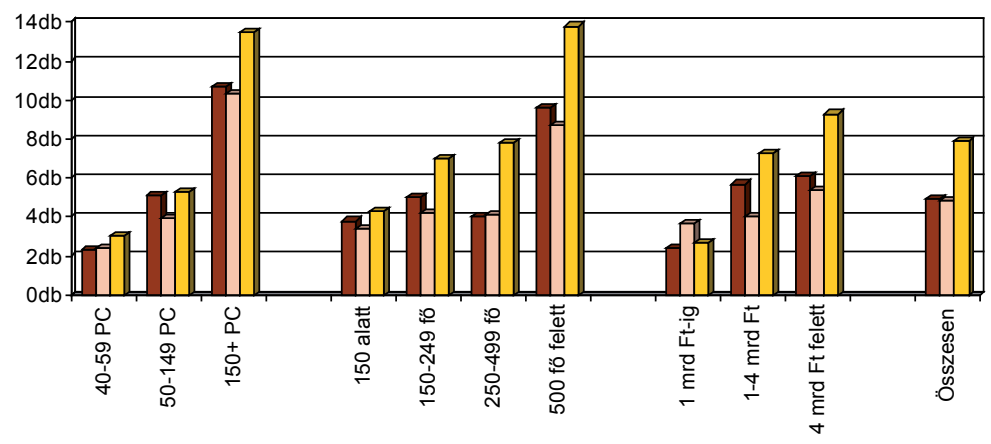

$\square$ Szerverként üzemelő PC

$\square$ Szerverházban müködő szervergép

$\square$ Rack-szekrényben müködő szerver gép

2. ábra

Az egyes szervertípusok átlagos száma 
A cégek 74\%-a csak egyféle típust használ, de az eszközök számával párhuzamosan növekszik az infrastruktúra heterogenitása. A szervert múködtetố vállalatok 49\%-a használ toronyszervert, vagyis ez a legelterjedtebb típus, de $40 \%$ feletti az úgynevezett rackszekrényben múködő változat, valamint a szerverként üzemelő PC-k penetrációja is.

Környezeti szempontból fontos kiemelni, hogy a szerverrel rendelkezó vállalatok négyötöde külön szerverszobát üzemeltet, amelyek túlnyomó többségénél (92\%) a helyiség hútéséról is gondoskodnak. A kutatás fontos eredménye, hogy a szerverszobát használó cégek átlagosan 12 szerverrel rendelkeznek, míg a nem használók átlagosan 4-gyel.

A nyomtatóhasználat a vállalatok körében 100\%-osnak tekinthetô. A használt nyomtatók átlagos száma 41.

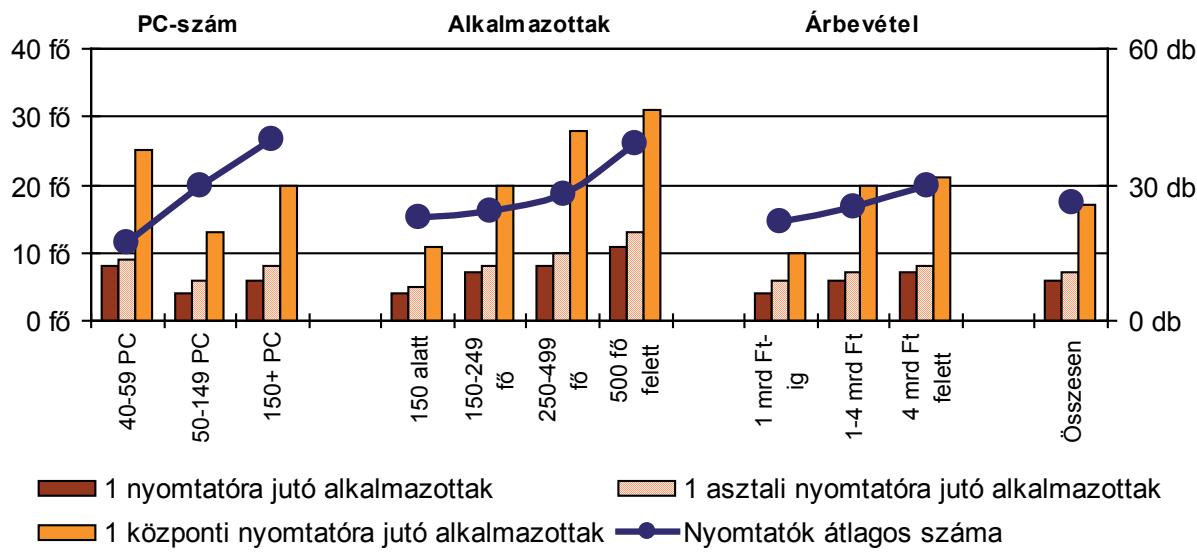

3. ábra

A nyomtatók által kiszolgált alkalmazottak átlagos sæáma

A nyomtatók esetében a darabszámnál fontosabb a kihasználtsági mutató, hiszen a hálózati megosztás segítségével egy nyomtató több ember munkáját is segítheti. Az asztali nyomtatók átlagos felhasználóinak száma 7 foó, tehát ennyi munkavállaló használja ugyanazt a nyomtatót, míg a központi nyomtatóknál 17 dolgozóra igaz ugyanez.

\section{Az informatikai infrastruktúra energiafogyasztása}

Megvizsgáltuk, hogy a vállalatokon belül mekkora energiafogyasztás köthetô a személyi számítógép- és szerverhasználathoz, illetve a szerverek hútéséhez. A válaszokból kiderült, hogy a vizsgált cégek több mint negyede (28\%) nem ismeri a PC-k energiafogyasztását. A szerverek fogyasztásával kapcsolatban 37\%-uk, a hútéssel kapcsolatban 45\%-uk nem tudott válaszolni. A hiányzó adatokra nézve a meglevố válaszok átlagából kiindulva becsléseket végeztünk, s ennek alapján készítettük el az energiafelhasználásra vonatkozó becslésünket. Megjegyezzük, hogy az összesítésben nemcsak az általunk tett becslések aránya magas, hanem valószínúsíthetôen maguk a válaszadók 
is több esetben becsült adatokat adtak meg, tehát a feltüntetett értékeket érdemes indikatívnak tekinteni.

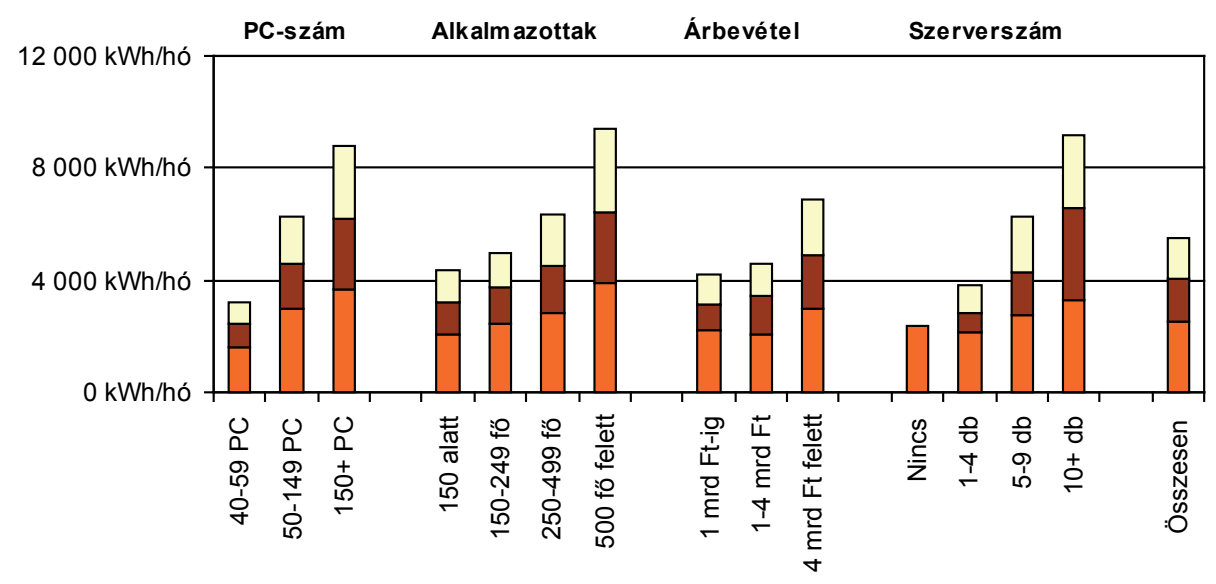

$\square$ PC-fogyasztás $\square$ Szerverfogyas zás $\square$ Szerverhűtés

4. ábra

Havi átlagos $P C$-és szerverfogyasztás vállalatonként (kWh/hó)

A vállalatok számítógépeinek átlagos teljesítménye kb. $230 \mathrm{~W}$. A számítógépek jellemzóen 300-400 W teljesítményú tápot használnak, azonban nem az összes teljesítményét használják fel az áramforrásuknak. A laptopok fogyasztása ugyanakkor csak 50 W körül van, s a hordozható számítógépek mára már jelentôs arányt képviselnek.

A szerverek átlagos teljesítménye $510 \mathrm{~W}$, amely magában foglalja a szerverként üzemelő PC-ket, a toronyházban és a rackszekrényben múködő szervereket is. A szerverek hútéséhez nagyjából ugyanakkora teljesítményre van szükség, mint a fútésükhöz, azaz a múködtetésükhöz. Ez az érték valamivel alacsonyabb lehet, mint a tényleges teljesítményük, azonban hútésre elsốsorban a nagyobb teljesítményú eszközöknél van szükség, s ezt figyelembe véve a számításoknál a hútoóteljesítményt is $510 \mathrm{~W}$-tal számoltuk.

A fentiek alapján egy PC havi átlagos fogyasztása 8 órás munkanapot feltételezve 36,8 kWh, s a számítógépek átlagos számát is belekalkulálva egy vállalat hozzávetóleg 5,6 MWh energiát használ fel havonta számítógépeinek múködtetésére. Egy szerver havi összfogyasztása körülbelül $367 \mathrm{kWh}$, vagyis a szerverek fogyasztása cégenként átlagosan 7-8 db eszköz esetén együttesen 2,9 MWh-ra rúg. A hútésre fordított teljesítményt ennek megfelelő́n 2,2 MWh-ra becsüljük, mivel a vizsgált vállalati körnek csak 80\%-a rendelkezik külön szobával, s ezek 92\%-a használ hútést.

Az ELMỨ honlapján található kalkulátor segítségével kiszámolható, hogy a fentiek alapján a vizsgált körben egy átlagos vállalat havonta nagyjából 500 ezer forintot fizet ki a számítógépek és a szerverek energiafogyasztására. Ez sok értelemben magyarázza a vállalatok magatartását, ami - tekintettel arra, hogy ennek az összegnek okos gazdálkodás esetén is csak egy része takarítható meg - racionálisnak tekinthetô. 
Valószínúleg úgy gondolkodnak, hogy az informatikai eszközök energiaköltségeinek csökkentése arányaiban több eróforrás ráfordítását igényelné, mint amennyi megtakarítható. Ez a magatartás azonban csak rövid távon indokolt, az informatikai eszközök energiafogyasztásával kapcsolatos szabályozás hosszabb távon már megtérülést hozna. Mmindössze 10\%-os megtakarítást feltételezve, egy átlagos vállalatnál kevesebb mint két év alatt már egymillió forint megtakarítás jelentkezhet.

Mivel a vizsgált vállalati körben 2500 cég múk ödik, a vállalatok összes havi energiafelhasználása körülbelül 26,8 GWh, azaz 96 TJ/hó. Egy átlagos háztartás energiafogyasztása 7 GJ havonta, azaz a legalább 40 számítógépet múködtetô vállalatok mintegy 15 ezer háztartás energiafogyasztásának megfelelố mennyiségú energiát használnak fel informatikai eszközeikre.

A nyomtatók energiafelhasználásával kapcsolatban a vállalatok 63\%-a nem tudott érdemben nyilatkozni. Mint a következókben látni fogjuk, a nyomtatási költségeknek és a nyomtatók áramfogyasztásának precíz, eszközönkénti nyomon követése nem jellemzó a vállalatokra, s az egységenkénti teljesítménynaplózást elsôsorban a kisebb méretú, kisebb eszközparkot fenntartó cégek tudják megoldani.

\section{Az eszközök életciklusa}

Mint fentebb is jeleztük, az energiafelhasználás csökkentéséhez nagymértékben hozzájárulhat egy szabályzat elkészítése, amely rögzíti az eszközökkel szemben támasztott legfontosabb követelményeket. Jelenleg az eszközök beszerzése során a vállalatoknak alig több mint a fele (54 százaléka) figyel oda a termékek környezetvédelmi minôsítésére, 42 százalékuk pedig egyáltalán nem foglalkozik ezzel.

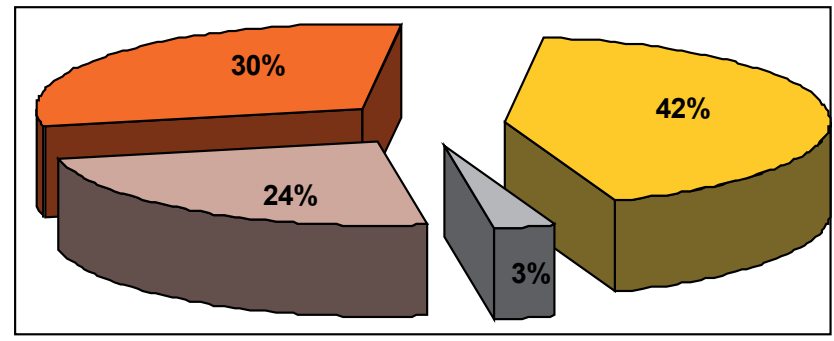

\section{$\square$ Nem tudja}

$\square$ Ad-hoc módon vizsgáljuk az eszközök minősítét $\square$ Csak megfelelő minősítésủ eszközöket vásárolunk $\square$ Nem foglalkozunk ezzel a kérdéssel

5. ábra

Szerepet játszik-e aะ Önök informatikai eszközbeszerzéseinél a termékek környezetvédelmi minösitése?

A vizsgált vállalati kör 48\%-ának van írott informatikai stratégiája, amely ezeknek a vállalatoknak a 29\%-ánál (azaz az összes vállalat 14\%-ánál) foglal magában valamilyen formában energiafogyasztással kapcsolatos eloórásokat. Részletesen kifejtett energiafogyasztási irányelveket a stratégiával rendelkezố vállalatok 8\%-a dolgozott ki. 


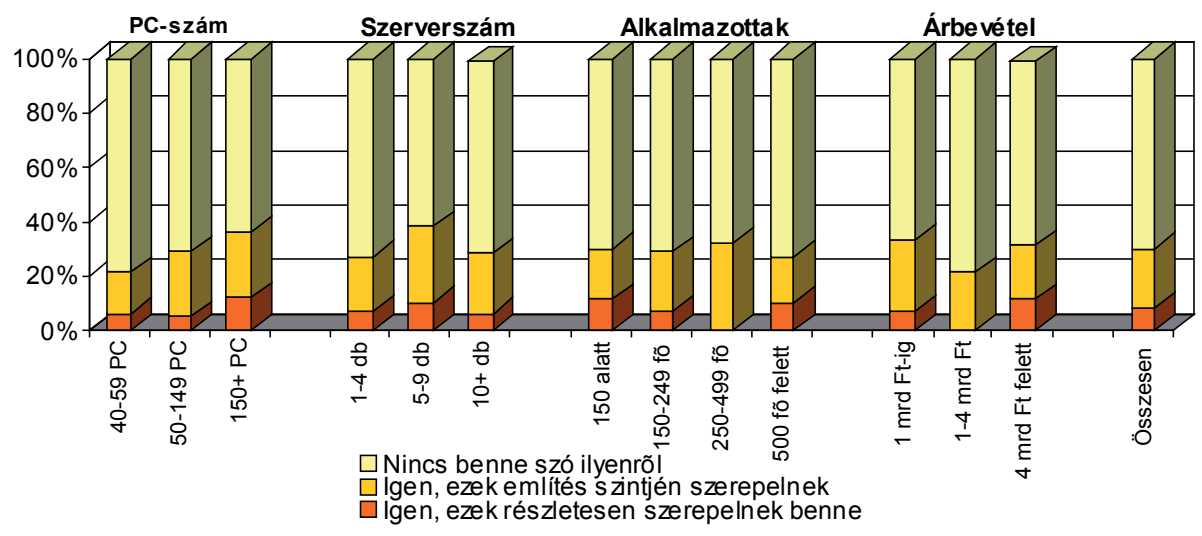

6. ábra

informatikai stratégiájuk tartalmaz-e elöírásokat az informatikai rendszerek energiafogyasะtására vonatkozóan?

A vállalatok energiatakarékossági törekvéseit a használatban levô eszközöket tekintve öt területen vizsgáltuk meg. A szerverhasználók körében a kedvezó energia- és erôforrás-kihasználásra való törekvés, valamint ennek megfeleloóen a szerverkonszolidáció megvalósítása képezte a vizsgálat fókuszát.

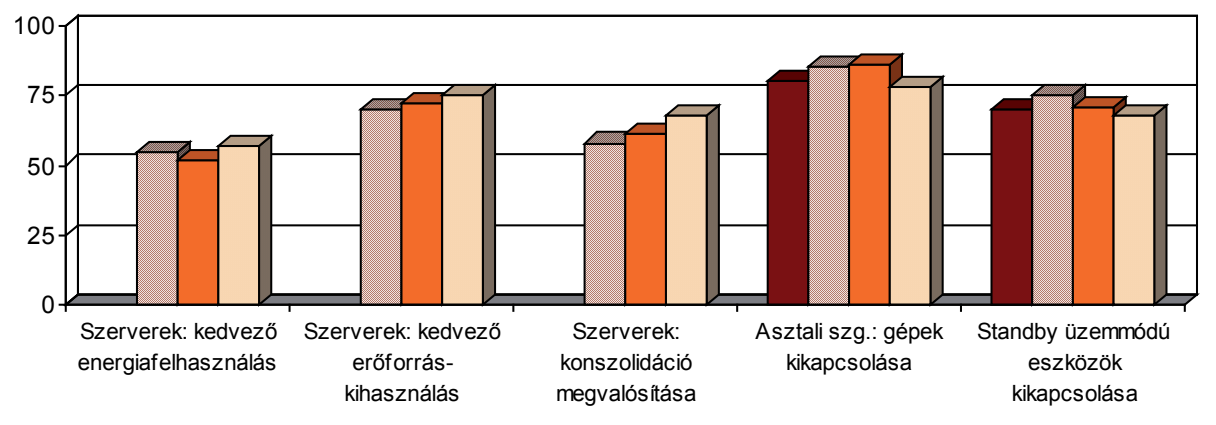

$\square$ Nincs $\square$ 1-4 db $\square 5-9 \mathrm{db} \square 10+\mathrm{db}$

7. ábra

Mekkora figyelmet fordítanak a alábbiakra?

(Az adott típusú eszközt használó cégek körében a szerverek száma szerint. Egyenlegértékek: 0 és 100 között, ahol 0 jelentése „egyáltalán nem figyelünk rá”, míg a 100 jelentése „teljes mértékben odafigyelünk rá”.)

A kedvezố energiafelhasználással kapcsolatban a vállalatok jellemzốn közömbösek, a szerverek fogyasztását nem tekintik fontos tényezónek. A kérdésre adott közömbös válaszokban szerepet játszhat az a feltételezés is a fogyasztók részéról, hogy a szállítói piacon érvényesüló éles verseny miatt nincs jelentôs különbség a szerverek fogyasztásában. Ezzel szemben a kedvezô eróforrás-kihasználásra már nagyobb figyelmet 
fordítanak, mivel ez elemi érdekük. A szerverek ára ugyanis meglehetósen magas, és kihasználatlan kapacitások mellett értelmetlennek tûnik újabb eszközöket vásárolni. Az eróforrás-kihasználási szempontok mellôzése a cégek számára jelentôs költségterhet jelenthet, azonban a tökéletes optimalizációnak is van költségvonzata. A vállalatok részéról erre fordított figyelem jellemzó mértéke annak tulajdonítható, hogy a „túlzott” optimalizáció szakértố-költsége meghaladja a lehetséges megtakarítás mértékét. A piac vélhetoóen erre a szintre „árazta be” a szakértối szolgáltatásokat.

Hasonló a helyzet a szerverkonszolidáció és -virtualizáció esetében is. A cégek nem teljesen közömbösek a konszolidációt illetốen, azonban az ezzel járó költségek és természetesen az ismerethiány miatt kevesebb forrást és figyelmet fordítanak az utólagos optimalizációra.

Az asztali számítógépek kikapcsolása nem jár extra költséggel, és többnyire már beleivódott a mindennapi felhasználási rutinba. Érdekes azonban, hogy az erre való odafigyelés még ennek ellenére sem magától értetôdő, és nem teljesen természetes, hogy a számítógépet a nap végén kikapcsoljuk. Az olyan stand-by üzemú eszközök (pl. monitorok) teljes áramtalanítására, amelyek a gyors elindulás érdekében elméletileg folyamatosan áram alatt vannak, szintén odafigyelnek, bár ez kevésbé jellemzố, mint a számítógépek kikapcsolása.

A nyomtatási takarékosság és a nyomtatók száma között nincs egyértelmú összefüggés. Az eszközök szintjén való monitorozás fóleg a kevés nyomtatót használó cégekre jellemzô, míg a teljes nyomtatási folyamat követése inkább a nagyobb eszközparkot múkködtetố vállalatoknál valósul meg. Minél több nyomtatója van egy vállalatnak, annál ritkábban fordul eló, hogy takarékoskodás csak az irányelvek szintjén történik. A központi nyomtatók használatát nemcsak kényelmi szempontok indokolják, az ezeket alkalmazó cégekre jellemzóbb a nyomtatási mennyiség és a költségek összesített monitorozása is. A vállalatok 52\%-a csak ,elméletileg”, az irányelvek szintjén, 36\%-uk összességében, $12 \%$-uk pedig az eszközök szintjén is figyeli a nyomtatási mennyiséget, s ezzel próbálja csökkenteni nyomtatási költségeit.

Fontos kérdés továbbá az informatikai eszközök selejtezése is, mivel a számítógépek alkatrészei a kommunális hulladékgyújtókbe kerülve nagy terhelést jelentenek a környezetre. Éppen ezért kötelezték a gyártókat és forgalmazókat arra, hogy az elektronikai hulladékot kötelesek legyenek visszavenni.

A vizsgált területek közül hazánkban az informatikai hulladék kezelése túnik a leginkább megoldottnak. A vállalatok selejtezési gyakorlata azt mutatja, hogy az informatikai eszközök többsége a leépítések során vagy házi használatba (28\%), vagy erre szakosodott cégek kezelésébe (52\%) kerül. A vállalatok egy része (14\%) a forgalmazónak vagy a beszállítójának adja vissza leselejtezendố eszközeit. Csupán 5\%-os azoknak a vállalatoknak az aránya, ahol az informatikai hulladék kezelésével nem foglalkoznak. 
Csak kp-i nyom tatója van

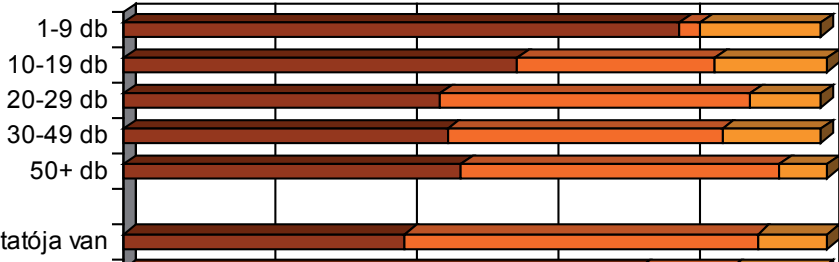

$1-3 \mathrm{db}$

$4-9 \mathrm{db}$

$10-19 \mathrm{db}$

20 vagy több

Csak asztali nyomtatója van
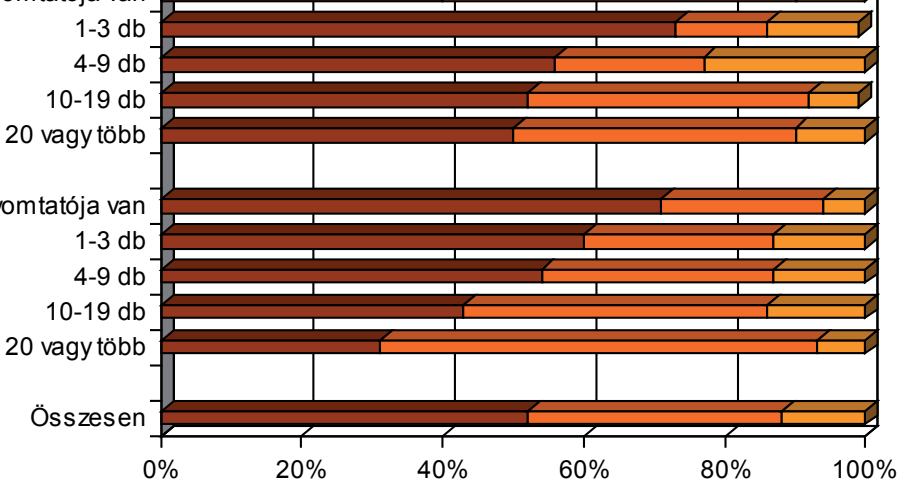

口 Számszerű mérés nincs, de irányelv szintjén törekszünk arra, hogy minél kevesebbet nyomtatssunk

$\square$ Nyomon követjük a teljes nyomtatási mennyiségünk és költségünk alakulását

$\square$ Eszközök szintjén figyeljük a nyomtatási teljesítményt és a költségeket

8. ábra

Figyelemmel kisérik-e Önök a vállalatnál a nyomtatási költségeket?

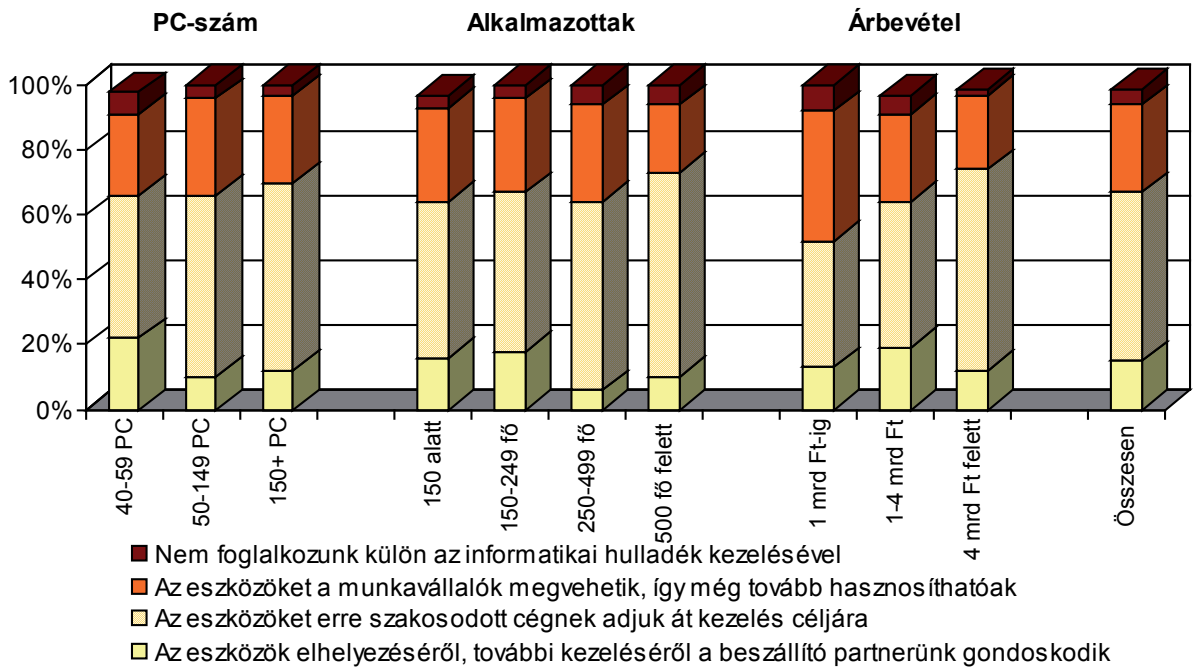

9. ábra

Milyen módon történik aะ Önök vállalatánál az informatikai eszközök selejtezése?

(Az összes megkérdezett vállalat körében, $n=302$ ) 
A felmérés eredményei megerôsítik, hogy a hazai középvállalatoknak még időre van szükségük az informatikai szempontból is környezettudatos magatartás elsajátítására. A folyamatban fontos szerepet játszik az informatikai stratégia elkészítése, mert ennek megjelenésével párhuzamosan egyre nagyobb figyelmet fordítanak az IT-eszközökre. Mindezek mellett általánosan igaz, hogy a nagyobb szakértelmet, több ismeretet igénylố tevékenységek esetében kevésbé elterjedt a környezettudatos magatartás: az IT hulladék megfelelő kezelése viszonylag elterjedt, ugyanakkor az energiafogyasztás optimalizálása még ritka jelenség. 